\title{
Age-related decrease in the activity of collagenase in the femoral head in patients with hip osteoarthritis
}

\author{
M. Zgoda • L. Pączek • I. Bartlomiejczyk • \\ J. Siemińska • D. Chmielewski • A. Górecki
}

Published online: 3 November 2006

(C) Clinical Rheumatology 2006

The online version of the original article can be found at: http://dx.doi. org/10.1007/s10067-006-0365-4.

M. Zgoda $(\varangle) \cdot$ D. Chmielewski $\cdot$ A. Górecki

Department of Orthopaedics and Traumatology

of the Locomotor System, The Medical University of Warsaw,

4 Lindley St,

02-005 Warsaw, Poland

e-mail: mzgoda@o2.pl

L. Pączek $\cdot$ I. Bartłomiejczyk

Department of Immunology, Transplantology

and Internal Medicine, The Medical University of Warsaw,

4 Lindley St,

02-005 Warsaw, Poland

\section{J. Siemińska}

Department of Experimental and Clinical Physiology,

The Medical University of Warsaw,

02-005 Warsaw, Poland
In the XML version of the online publication the family name of the second author was incorrectly given as Pczek. In fact, the correct family name is Paczek. 